\title{
ZERO HOURS CONTRACTS
}

\author{
JAN PICHRT*
}

\begin{abstract}
Zero hours contracts
The article focuses on comparing details and differences (Zero hours contracts) in British labour law with the performance of work on the basis of Czech agreements on out-of-work contracts and influence these non-standard labour relations on employment policy and possible negative effects on labour-law securities.
\end{abstract}

Keywords: Zero hours contracts; exclusivity clause; labour-law securities

Klíčová slova: Zero hours contracts; doložka exkluzivity; pracovněprávní jistoty

DOI: $10.14712 / 23366478.2019 .7$

\section{I. ÚVODEM K ATYPICKÝM PRACOVNĚPRÁVNÍM VZTAHŮM A K PODKOPÁVÁNÍ PILÍŘŮ PRACOVNÍHO PRÁVA}

Téměř ve všech zemích, které lze podřadit pod skupinu „rozvinutých ekonomik“, přitahují tzv. atypické pracovněprávní vztahy trvale pozornost právní teorie ${ }^{1}$ i praxe. Pokud jde o oblast právní teorie, je tomu tak i proto, že většina autorù věnujících se tomuto tématu vnímá určité dilema, které stále pestřejší množina těchto vztahů přináší. Na straně jedné je nepochybné, že technologický pokrok a s ním související změny ve způsobu výkonu práce v mnohých profesích (včetně „mizeni'“ některých druhů práce a „objevování“ nových profesí) vedou v některých př́padech k potřebě reflektovat tyto změny i určitou modifikací „klasických“ právních vztahů, ve kterých je závislá práce konána. Na straně druhé je stále patrnější, že ono „přizpůsobení se novým potřebám a trendům“, které je (částečně oprávněně) dáváno do korelace s vytvářením nových pracovních míst či se zaměstnaností těch, kteří by se v „klasickém uspořádáni““

* Autor je vedoucím katedry pracovního práva a práva sociálního zabezpečení Právnické fakulty Univerzity Karlovy (Praha), hlavním řešitelem Výzkumného centra UNCE/HUM/034 „Závislá práce v 21. století otázky a výzvy“, předsedou České společnosti pro pracovní právo a právo sociálního zabezpečení, členem Komise pro pracovní právo a sociální věci Legislativní rady vlády ČR, advokátem a rozhodcem zapsaným na listině rozhodců Rozhodčího soudu při HK ČR a AK ČR.

1 I na Právnické fakultě UK se této problematice dlouhodobě věnujeme, srov. např. PICHRT, J. - MORÁVEK, J. (eds.). Atypická zaměstnávání - cesta k vyšši zaměstnanosti? Praha: Wolters Kluwer, 2015, 336 s. ISBN 978-80-7478-975-5. 
do pracovního procesu zapojit nemohli, je mnohými aktéry teorie i praxe obratně využíváno $\mathrm{k}$ postupné destrukci pracovního práva (minimálně v jeho evropském a sociálním pojetí). Frázemi o nutnosti „reflektovat technologický pokrok“ jsou občas zakrývány nejrůznější snahy zaměstnavatelů „vyvádět“ výkon mnohých (dosud závislých) prací $\mathrm{z}$ „ochrany“ pracovního práva do oblasti „odběratelsko-dodavatelských“ vztahů a jiné postupy přispívající $\mathrm{k}$ postupné erozi piliŕr̆ů, na kterých pracovní právo dosud stojí, a doufejme, že i do budoucna stát bude.

Český právní rád (stejně jako např. právní rád Spojeného království Velké Británie a Severního Irska) neobsahuje vymezení pojmu atypická zaměstnání. Typické pro atypická zaměstnání je navíc to, že jejich okruh není vnímán ani doktrinálně zcela jednotně. Není to překvapující, vezmeme-li v úvahu, že ani obsah jejich ,jazykového protipólu“ - tedy „typického zaměstnáni“ - nemusí být vnímán zcela jednotně².

Část teorie považuje za „typické zaměstnáni““ (či možná „nejvíce žádoucí) pracovněprávní vztah sjednaný na plný úvazek a na dobu neurčitou (někteří autoři $\mathrm{k}$ tomu připojují atribut konání práce na pracovišti zaměstnavatele). $Z$ výše uvedených znaků je pak zřejmé, že výkladem a contrario vymezená množina atypických pracovních poměrů by byla velmi široká3 .

Přes různost pohledů na šíri množiny atypických pracovněprávních vztahů se většina teorie (evropské) shoduje v tom, že mezi ně patří pracovní poměry na dobu určitou a pracovněprávní vztahy realizované $\mathrm{v}$ rámci agenturního zaměstnávání, $\mathrm{v}$ širším slova smyslu pak i práce na částečný úvazek. Podíváme-li se však do prací věnujících se pracovnímu právu ve Velké Británii, zjistíme, že autoři do této skupiny podřazují i tzv. zero hours contracts ${ }^{4}$ (které bývají někdy označované též jako „,nil-hours contracts" ${ }^{\text {“5 }}$ ), a současně někteř́ neopomenou zdůraznit, že právě s výjimkou naposled uvedeného pracovněprávního vztahu je právní úprava atypických pracovněprávních vztahů ovlivněna právem EU a reflektuje koncept „flexicurity“. 6 To jistě vzbudí pozornost každého badatele; pojd’me se tedy blíže podívat na tento, unijními koncepty nedotčený, právní instrument.

2 Bliže k problematice atypických zaměstnání srov. též PICHRT, J. Několik úvah k budoucímu směřování vývoje atypických zaměstnání. In: Liberalizácia právnej regulácie pracovných vzt'ahov v podmienkach globalizácie. Zborník príspevkov z medzinárodnej vedeckej konferencie „Právo ako zjednocovateí Európy - veda a prax“, slovenská čast', s. 183-189. Bratislava: Univerzita Komenského, PF, 2011.

3 Srov. PICHRT, J. Některé aspekty atypických zaměstnání a zaměstnanosti z pohledu individuálního i kolektivního pracovního práva. In: PICHRT, J. - MORÁVEK, J. (eds.). Atypická zaměstnávání-cesta k vyšši zaměstnanosti? Praha: Wolters Kluwer, 2015, s. 11 a násl. Shodné vymezení atypických pracovněprávních vztahů jako shora srov. DAVIS, A. C. L. Employment Law, Pearson Education Limited, 2015, ISBN 978-1-4082-6360, s. 120.

4 V anglické odborné literatuře se lze běžně setkat jak s variantou s pomlčkou (,zero-hours contracts“) tak s variantou bez pomlčky (,,zero hours contracts"). Někteří autoři používají jako synonymum též tvar „zero-hours work“ (též s pomlčkou i bez pomlčky) či i jen zkrácenou formu ,zero hours“; v následujícím textu bude nadále používán především tvar ,zero hours contract(s)“.

5 Srov. NAPIER, B. - SMITH, I. S. - EADY, J. - MCMULLEN, J. - BRENNAN, T. Harvey on Industrial Relations and Employment Law (HIREL). LexisNexis UK. ISBN/ISSN: 9780406048110. Issue 259, 57.01.

6 Např. DAVIS, A. C. L. Employment Law, Pearson Education Limited, ISBN 978-1-4082-6360, 2015, s. 120. 


\section{ZERO HOURS CONTRACTS}

Pro stručnou charakteristiku úvodem je možné uvést, že označení „,zero hours contracts“ je v oblasti pracovněprávních vztahů ve Spojeném království obecně užíváno k označení takových smluv, které nezaručují minimální objem odpracované doby, resp. ve kterých není garantován minimální hodinový rozsah přidělované/konané práce. Množství takových smluv v posledních letech strmě roste $\mathrm{v}$ oblastech jako pečovatelství, služby v pohostinství apod.7 Ze smluv, které bývají dosud často označovány jako př́ležitostné ${ }^{8}$ (nebo „přerušované“ či , podle potřeby“"9), se stávají smlouvy stále více oblíbené mezi zaměstnavateli (což není ve své podstatě překvapivé s ohledem na výhody /či spíše úlevy v podobě neposkytování některých plnění/, které zaměstnavatelům skýtají oproti standardním zaměstnaneckým vztahům - viz níže).

Mnozí britští autoři také upozorňovali, že shora zmíněná terminologie není v právu pevně ukotvena a zmíněná označení mohou být použivána pro více různých typů uspořádání pracovněprávních vztahů..$^{10}$ Bylo též poukazováno, na to, že z pohledu common law se jedná v podstatě o ekonomickou, nikoliv právní kategorii ${ }^{11}$. I materiál, který britská vláda připravila jako podklad ke konzultacím o možné budoucí právní úpravě používání ,zero hours contracts“, v roce 2013 uváděl: „Neexistuje legální definice ,zero hours contracts 'v národním právu. Obecně platí, že , zero hours contracts ' je zaměstnanecká smlouva, ve které zaměstnavatel nezaručuje jednotlivci práci a jednotlivec není povinen príimout žádnou nabídnutou práci. "12 Je zde na místě podotknou, že redukcí smluvních typů, které lze zahrnout pod ,zero hours contracts“ na zaměstnaneckou smlouvu (an employment contract), „si to“ vládní materiál velmi (na úkor přesnosti) zjednodušil, jak bude i dále rozebráno. Ilustrativní je vládním materiálem uvedený př́iklad vzorové klauzule činící ze smlouvy smlouvu typu ,zero hours contracts“: „Společnost nemá nikdy povinnost poskytnout vám jakoukoliv práci, vy nemáte povinnost prijimout jakoukoli práci kdykoliv Vám nabídnutou společností."13

Postupně rostoucí obliba či spíše četnost užívání smluv zařaditelných pod „,zero hours contracts" ukázala ve Spojeném království na mnohé problémy s nimi spojené.

Především to byl sám fakt nejistoty ohledně ,zaměstnaneckého“ statusu pracovníků takové práce konající a $\mathrm{z}$ toho plynoucí nejistota stran jejich zaměstnaneckých práv, jakož i fakt, že takoví zaměstnanci nemají zaručenu žádnou minimální úroveň pravidelného př́ijmu.

7 Srov. LEWIS, T. Employment law: an adviser's handbook. 12th edition. Legal Action Group. ISBN 9781908407948, 2017, s. 20.

8 Mezi „casual contracts“ jsou tyto smlouvy zahrnuty např. v publikaci EMIR, A. Law of Employment, Oxford University Press, 20th Edition, ISBN 978-0-19-881484-9, 2018, s. 78.

9 Intermittent or as required - srov. DAVIS, A. C. L. Employment Law, Pearson Education Limited, ISBN 978-1-4082-6360, 2015, s. 120.

10 Srov. DAVIS (viz shora) a shodně s ním např. LEWIS, T. (viz shora).

11 Srov. HIREL. Issue 259, 57.01.

12 Department for Business, Innovation and Skills. Consultation: zero hours employment contracts, 2013, dostupné online na: <https://assets.publishing.service.gov.uk/government/uploads/system/uploads /attachment_data/file/267634/bis-13-1275-zero-hours-employment-contracts-FINAL.pdf>.

13 „The Company is under no obligation to provide work to you at any time and you are under no obligation to accept any work offered by the Company at any time. "Tamtéž. 
K problému negarantovaného prŕíjmu Davis ${ }^{14}$ uvádí: „Jestliže se zaměstnavatel nezavázal k žádnému určitému objemu práce, může se individuálni výdělek lišit od týdne $k$ týdnu a mũže být v některém týdnu nulový. "15 a dodává, že to jednotlivcům v takové situaci nejen ztěžuje osobní finanční hospodaření, ale může také způsobit obtíže z pohledu poskytovatelů dávek sociálního zabezpečení, kterým bude nějakou dobu trvat, než se „vypořádaji“ s kolísáním příjmů (a vyhodnocením splnění podmínek nároku) na straně potenciálního subjektu dávek - zaměstnance s takto nepravidelným př́ijmem; dodejme - avšak stále ,pod smlouvou“ k zaměstnavateli, i když jen nepravidelně naplňovanou, pouze občasně poptávanou a následně vykonávanou prací.

Pokud bychom porovnali popisovanou britskou praxi se stávající českou pracovněprávní úpravou, musíme konstatovat, že i náš právní řád zná pracovněprávní instituty, které ve svém důsledku nemusí (předem) garantovat, že zaměstnanec odpracuje v určitém období určitý objem (hodin práce) a mohou vést v některém kalendářním měsíci i k efektu ,zero hours"16. Mnohé dohody o pracích konaných mimopracovní poměr (zejména dohody o provedení práce ve školství apod.) jsou v podstatě koncipovány jako právní rámec „práce na vyžádáni““ (např. na vysokých školách nemusí být dopředu zřejmé, kolika přednáškami, posudky, či počtem zkoušení bude dohoda o provedení práce „naplněna“, a tedy jaká „časová dotace“ bude na plnění dohody měsíčně věnována); konečně český zákonodárce $\mathrm{v} \S 74$ odst. 2 zákoníku práce šel této možnosti „naproti“ tím, že stanovil: „(2) V dohodách o pracích konaných mimo pracovni poměr není zamèstnavatel povinen rozvrhnout zaměstnanci pracovni dobu."

Český právní rád sice formulací § 74 dost. 1 ZPr: „(1) Zaměstnavatel má zajištovat plnění svých úkolů předevšim zaměstnanci v pracovním poměru." formálně preferuje pracovní poměr jako „typický“ pracovněprávní vztah, současně ale (podtrhuji, že v současné době, nebylo tomu tak vždy, srov. dobová znění obdobného ustanovení) v zákoníku práce použitá formulace (viz výše) z tohoto ustanovení dělá proklamativní text, $v$ podstatě nenormativního charakteru.

Česká varianta „zero hours“ však v praxi zásadní problémy nečiní (zejména zákonným omezením rozsahu práce, která na jejich základě může být konána), konečně i česká pracovněprávní teorie označuje tyto vztahy za „doplňkové pracovněprávní vztahy“, když je zřejmé, že těžiště pracovněprávních jistot (a v neposlední řadě odpovídajícího výdělku) a souvisejících práv v oblasti sociálně-právní, by měli ti, kteří „mohou a chtějí pracovat“, nacházet v navazování ne-doplňkových pracovněprávních vztahů. Pokud uzavřeme toto stručné srovnání, pak drtivá většina „českých dohodářu“ “ vnímá tyto doplňkové pracovněprávní vztahy opravdu doplňkově, nebot’ mají vedle nich zpravidla

\footnotetext{
4 DAVIS, A. C. L., Employment Law, Pearson Education Limited, ISBN 978-1-4082-6360, 2015.

5 DAVIS, A. C. L., Employment Law, Pearson Education Limited, ISBN 978-1-4082-6360, 2015, s. 121.

${ }^{16}$ Lze se setkat ojediněle i s př́ípady, kdy uzavřená dohoda o provedení práce není v období, na které je uzavřena, z různých důvodů vůbec „konzumována“. Autor je toho názoru, že pokud v dohodě o provedení práce není předem sjednán objem práce (pracovní doby), jejíž odpracování by zaměstnavatel zaměstnanci předem garantoval, nemůže být konečný „,nulový“ součet odpracovaných hodin v rozporu s právem; stranou této stručné úvahy byly záměrně ponechány možné varianty specifických okolností každého případu, které mohou mít vliv na různá „,vstupní“ očekávání stran a na posouzení jejich důvodnosti, včetně možných následků.
} 
navázán (více či méně) „plnohodnotný“ pracovní poměr, případně patří do skupiny „pracujících důchodců“, studentů či jiných „státních pojištěnců“.

Ve Velké Británii je však situace při užívání ,zero hours contracts“ zjevně odlišná, i proto se ve Spojeném království vedla (a částečně dosud vede) stran těchto smluv poměrně vyhraněná diskuse.

Bylo by nad rámec zamýšleného rozsahu tohoto př́íspěvku věnovat se na tomto místě poněkud obsáhlejší materii, kterou by čtenáři bylo nutné přiblížit pro objasnění, na základě jakých kritérií a s jakými důsledky rozlišuje britské právo mezi zaměstnanci a pracovníky, resp. přesněji, za užití anglické terminologie, mezi „employee“ a ,worker"; tomuto (v některých aspektech nepochybně inspirujícímu) rozlišování se budeme blíže věnovat v některých dalších publikačních výstupech našeho výzkumu. Na tomto místě proto pouze zjednodušeně uvedeme, že postavení „employee“ ve Spojeném království je v zásadě obdobou zaměstnance pracujícího v pracovním poměru ve smyslu českého pracovního práva, zatímco ,worker“ přiléhavou obdobu v českém pracovním právu nemá - pracuje sice osobně za odměnu na základě smlouvy nebo jiné dohody, z pohledu srovnání s českým pracovním právem se však nachází „na přechodu“ mezi ,zaměstnancem“a „osobou samostatně výdělečně činnou“ (,self-employed person“). Materiál, který britská vláda zpracovala v roce 2013 v rámci konzultací vedených k tématu „Zero hours employment contracts “ $\mathrm{k}$ tomu uvádí: „... kategorie pracovník (, worker ') je často vnímána jako hybrid zaměstnance (,employee") a statusu osoby samostatně výdělečně činné (, self-employed person'). ,Pracovnici ' mají méně ochrany než ,zaměstnanci ‘ $v$ domácím pracovním právu. Všichni, zaměstnanci ‘jsou, pracovníci‘. Ne všichni ,pracovníci 'však budou ,zaměstnanci ‘."17

Opět bychom mohli konstatovat, že z českého pohledu - nazíráno prizmatem dohod o pracích konaných mimo pracovní poměr - v zásadě „nic překvapivého“. Zaměstnanci v ČR jsou zvyklí na fakt, že jejich nároky jsou v těchto oblastech také zásadně zúžené oproti zaměstnancům pracujícím v pracovním poměru; rozdíl zde však je - je třeba opět zdůraznit, že tyto „méně chráněné““ pracovněprávní vztahy jsou v ČR jen ,doplňkové“.

Pro účely dalšího výkladu je však možné zjednodušeně uvést, že pro oba typy těchto zaměstnaneckých vztahů (employee/worker) platí, že pokud jednotlivec vykonává práci na příslušném smluvním základě, je možné dovozovat, že je zaměstnancem/pracovníkem (i když nikoliv s úplným vyloučením opačného závěru v konkrétním případě může mít ojediněle i postavení ,self-employed person“"), který má v případě výkonu práce nárok na zaměstnanecká/pracovní práva jako je minimální mzda ${ }^{18}$ („National Minimum Wage“19).

Davis v této souvislosti upozorňuje, že je však nepravděpodobné, že by někdo se ,zero hours contract“ mohl získat na delší dobu status ,employee“, tedy zaměstnance (např. za účelem možnosti obrany proti neoprávněnému propuštění nebo za účelem

17 „All 'employees' are 'workers'. However not all 'workers' will be 'employees'. “ Department for Business, Innovation and Skills. Consultation: zero hours employment contracts, 2013, dostupné online na: $<$ https://assets.publishing.service.gov.uk/government/uploads/system/uploads/attachment_data /file/267634/bis-13-1275-zero-hours-employment-contracts-FINAL.pdf >.

18 Srov. DAVIS, A. C. L. Employment Law, Pearson Education Limited, ISBN 978-1-4082-6360, 2015, s. 121.

19 Okolo 5 \% pracovníků ve Spojeném království dostává za práci minimální mzdu, srov. tamtéž, s. 240. 
vzniku nároku na odstupné při skončení pracovního poměru) a uzavírá, že je tomu tak pro neexistenci vzájemných povinností, s ohledem na absenci príslibu (povinnosti) poskytovat práci ze strany zaměstnavatele; pokud jsou v realizaci zaměstnání (ve výkonu práce) významné přeryvy, nemusí být též naplněna kontinuita zaměstnání, se kterou zákon tyto nároky spojuje ${ }^{20}$. Současně však Davis upozorňuje (tamtéž) na rozhodnutí Pulse Healthcare Ltd $v$ Carewatch Care Services Ltd \& Others [UKEAT/0123/12/BA]; na totéž rozhodnutí odkazuje i shora zmíněný konzultační materiál britské vlády, který uvádí: „Existuji mylné názory, že osoba pracujici pod, zero hours contract “ nemůže být nikdy zaměstnancem. To je nesprávné. Existuje judikatura Employment Appeal Tribunal (EAT), která přiznala status zaměstnanců (the employment status) zdravotním sestrám poskytujicim služby intenzivni péče, které pracovaly ve směnách rozvržených na základě ,zero hours contract'. EAT konstatoval, že písemné smlouvy neodrážejí skutečné postaveni stran. Zdravotni sestry nepracovaly ad hoc, ale pracovaly na svých pracovnich mistech, v pevně určeném čase pravidelně po několik let. EAT konstatoval, že zdravotní sestry byly zaměstnány na základě globálnich pracovnich smluv a nebyly žádné potiže s prokázáním kontinuity jejich zaměstnání. “21

Je zřejmé, že Odvolací pracovní tribunál (EAT) v této otázce věc posuzoval dle způsobu realizace obsahu smluvního ujednání, ne dle deklarované formy, resp. označení vztahu jeho stranami; ostatně dle obdobných principů by při posuzování obdobné věci postupovaly i soudy české. Již citovaná monografie kolektivu autorů (HIREL), $\mathrm{k}$ tomu uvádí: „Jestliže z podobného uspořádání vztahů vzniknou spory, soud či tribunál budou aplikovat prirozené principy (viz např. použití konceptu falešnélzastřenéltransakce $v$ prípadu Pulse Healthcare).“22

Prozatím jsme mohli konstatovat, že přes mnohá specifika britské právní úpravy lze najít v některých bodech i paralely ,zero hours contracts“ $\mathrm{s}$ dohodami o pracích konaných mimo pracovní poměr. Co však českého čtenáře zřejmě zarazí - a hledal by tuzemskou paralelu marně - je (či spíše byl) výskyt doložek exkluzivity v těchto smlouvách.

Ve Velké Británii v nedávné minulosti docházelo $\mathrm{k}$ tomu, že zaměstnavatelé požadovali po zaměstnancích uzavírání ,zero hours contracts“, které obsahovaly též ujednání o výhradnosti (,exclusivity clause“), stanovící, že zaměstnanec musí poskytovat svoje služby (práci) výlučně tomuto zaměstnavateli.

I bez této doložky je možnost zaměstnanců pracujících na základě ,zero hours contracts" přijmout jinou (další) práci poměrně limitována. Je tomu tak zejména proto, že se tito zaměstnanci obávají, že může dojít k situaci, že by po nich byla práce požadována ve stejné době z obou smluvních vztahů (od obou zaměstnavatelů). Zaměstnanec se tak obává, že pokud zaměstnavatel zavolá a zaměstnanec nebude připraven nastoupit k výkonu požadované práce, nemusí již být k práci příště vyzván nebo bude zhoršeno /sníženo/ jeho pořadí v rámci všech zaměstnanců čekajících na prríští zavolání; Davis k tomu uvádí, že u těchto druhů práce taková „pořadí“ existují a v rámci těchto pořadí je práce ve chvíli, kdy se „objevi““, častěji (přednostně) nabízena těm, kteří pracují (re-

\footnotetext{
20 Tamtéž, s. 121.

21 Consultation: zero hours employment contracts, s. 25.

22 HIREL, Issue 259, 57.01.
} 
flektují zavolání) pravidelně23. V tomto ohledu stojí za pozornost, že u mnohých z těchto zaměstnavatelů existují podobné systémy „hodnocení“ připravenosti zaměstnanců „naskočit do procesu“, jaké známe z případů „spolupracovníků“ pracujících pro různé platformy v rámci „ekonomiky sdílení“; je zřejmé, že obavy z celosvětově postupující „uberizace“ práce, jednoznačně spojené s mizením klasických pracovních míst a jejich „nahrazování“ pseudo-dodavatelskými vztahy s minimální ochranou, nejsou v tomto ohledu liché24.

Právě existenci a nadužívání doložek exkluzivity identifikovala britská vláda při zahájení shora uvedených konzultací v roce 2013 jako jedno z rizik, v prrípadě, kdy tyto doložky: „... brání tomu, aby jedna osoba pracovala pro jiného zaméstnavatele, $i$ když současný zaměstnavatel nenabizi žádnou práci“ ${ }^{25} \mathrm{Na}$ druhé straně sám fakt, že na základě ,zero hours contracts“ v té době pracovalo ve Spojeném království již okolo 250000 pracovníků, dával tušit, že úplní odpůrci ,zero hours contracts“ se naplnění svých očekávání zřejmě nedočkají. Tomu, že britská vláda v podstatě již dopředu přistoupila ke konzultacím s tím, že institut stále více oblíbený mnohými zaměstnavateli ve své podstatě ,podrží“, ostatně napovídala již formulace předmluvy, kterou pro konzultační materiál připravil státní tajemník pro podnikání, inovace a dovednosti a předseda obchodní rady, člen sněmovny Vince Cable, ze které je možné pro ilustraci ocitovat: „Vláda se zavázala k dosažení flexibilního a spravedlivého trhu práce. Politikou vlády je vytvořit u zaměstnavatelì di̊věru k prijímání nových zaměstnanců a $k$ vytvárení nových pracovnich mist a poskytnout rámec, který jednotlivcům umožní nejen najít práci, ale najít práci, která vyhovuje jejich individuálním potřebám. ... ,Zero hours contracts “ jsou v některých odvětvích používány zodpovédně po mnoho let. Mohou podporovat flexibilitu podnikání, usnadnit nábor nových zaměstnanců a poskytnout mladým lidem cestu $k$ zaměstnání. Tyto smlouvy a dalši pružná opatření dávají jednotlivcưm možnost většiho výběru a možnost sladění práce s ostatními závazky ... “26

Davis k tomu uvedl, že vládní konzultace byla komentátory „odsouzena“ proto, že v principu přijala zero hours working jako legitimní formu uspořádání, které přináší flexibilitu pracovnímu trhu ve prospěch pracujících stejně jako zaměstnavatelů. ${ }^{27}$

V podstatě jediným př́mým důsledkem vládních konzultací na podobu britského právního řádu byl zákaz sjednávání doložek exkluzivity v ,zero hours contracts“, který byl realizován vložením nových ustanovení (Section 27A a 27B) do The Employment Rights Act 1996 (ERA), prostřednictvím Small Business, Enterprise and Employment Act 2015. S účinností od 11. ledna 2016 označuje zákon jakékoli ustanovení ,zero hours contract“, které zakazuje pracovníkovi vykonávat práci nebo vykonávat služby na základě jiné smlouvy nebo jiné dohody, nebo podmiňuje výkon takové práce přechozím souhlasem zaměstnavatele, za nevymahatelné vůči pracovníkovi.

23 Srov. DAVIS, A. C. L., Employment Law, Pearson Education Limited, ISBN 978-1-4082-6360, 2015, S. 121.

$24 \mathrm{~K}$ tomuto jevu srov. např. PICHRT, J. - BOHÁČ, R. - ELISCHER, D. - KOPECKÝ, M. - MORÁVEK, J. (eds.). Sdílená ekonomika a delikty. Praha: Wolters Kluwer ČR, 2018.

25 Consultation: zero hours employment contracts, s. 5.

26 Tamtéž, s. 4.

27 Srov. DAVIS, A. C. L., Employment Law, Pearson Education Limited, ISBN 978-1-4082-6360, 2015, S. 122. 
Paradoxně tak v důsledku shora uvedených konzultací došlo sice k zákazu skandálních doložek exkluzivity (na jejichž základě zaměstnavatel, který pro zaměstnance práci neměl a ani mu ji nemusel nabídnout, přesto vyžadoval, aby tento zaměstnanec nepracoval ani pro nikoho jiného - tedy mj. omezoval zaměstnance bezekvivalentně a se všemi škodlivými dopady na trh práce, včetně dopadu do oblasti sociálních dávek, jejichž uživateli se takto $\mathrm{z}$ trhu práce vyřazení $\mathrm{v}$ důsledku často stávali), avšak současně došlo k tomu, že se dosud pouze „kategorie ekonomická“ (viz HIREL výše) stala „kategorií právní“, nebot' v ustanovení 27A ERA nově obsahuje i definici těchto smluv. I když se zdánlivě jedná o vymezení těchto smluv pouze pro účely zákazu doložek exkluzivity, je zřejmé, že britská právní definice ,zero hours contracts“ spatřila „světlo světa“. Britská vláda, tím nepochybně zcela vzala naděje zastáncům úplné eliminace tohoto institutu a naopak potěšila všechny zaměstnavatele používající tento nástroj, tak nehezky evokující scény z historických filmů o najímání dělníků v době krize na jeden den jejich výběrem $\mathrm{z}$ davu na bráně továrny.

V říjnu 2015 pak došlo k vydání vládních pokynů pro zaměstnavatele týkajících se ,zero hours contracts“ (Zero hours contracts: guidance for employer). ${ }^{28}$ Je např. doporučováno neuživat ,zero hours contracts“ pro účely zajištění hlavního předmětu činnosti (hlavní služby), a pokud jsou použivány, doporučuje se věnovat co nejvíce pozornosti procesu nabízení $i$ ukončování výkonu práce na jejich základě. Lze souhlasit $\mathrm{s}$ Lewisovou ${ }^{29} \mathrm{v}$ tom, že tyto pokyny sice stanovily postupy pro správnou praxi, nejsou však právně vynutitelné a nevyřeší tedy skutečné potíže, kterým čelí zaměstnávání na základě takových smluv.

Závěrem je možné konstatovat, shodně s většinou teoretiků pracovního práva, že (vedle) mnohých pozitiv) je rozšiřování atypických pracovněprávních vztahů též jedním z důvodů zhoršeného dodržování a „vymahatelnosti“ pracovněprávních předpisů. Davidov k tomu uvádí, ${ }^{30}$

že práce na částečný úvazek, $\mathrm{z}$ domova, $\mathrm{v}$ nepravidelném rozvržení, práce na základě ,zero hours contracts“ nebo v jiném ,atypickém“ uspořádání, má dva významné důsledky z hlediska dodržování práva a jeho vymahatelnosti. Prvním důsledkem je, že tyto druhy ,zapojení“ zaměstnanců vedou ve svém důsledku k menší četnosti kontaktů mezi pracovníky pracujícími pro stejného zaměstnavatele, což v důsledku vede $\mathrm{k}$ tomu, že tito pracovníci jsou méně obeznámeni se svými právy, resp. si je méně uvědomují a oslabeno je i jejich vlastní úsilí o jejich prosazování. Druhým následkem je omezení schopnosti orgánů inspekce práce účinně působit $\mathrm{k}$ prosazení zákona $\mathrm{v}$ rámci takto „rozptýlených“" pracovních sil.

Je zjevné, že výhody i nevýhody veškerých atypických aranžmá v pracovněprávních vztazích by měly být zákonodárcem vždy uvážlivě zvažovány; skutečně fungující so-

28 Dostupné online na: <https://www.gov.uk/government/publications/zero-hours-contracts-guidance-for -employers/zero-hours-contracts-guidance-for-employers $>$.

29 Srov. LEWIS, T. Employment law: an adviser's handbook. 12th edition. Legal Action Group. ISBN 9781908407948, 2017, s. 21.

30 DAVIDOV, G. A Purposive Approach to Labour Law. Oxford University Press 2016. Published 2016 by Oxford University Press, s. 228. 
ciální dialog nad nově vytvářenou pracovněprávní legislativou by pak měl být garancí před přijímáním podobně nevyvážených modelů.

prof. JUDr. Jan Pichrt, Ph.D.

Právnická fakulta Univerzity Karlovy

pichrt@prf.cuni.cz 